\title{
Automated tone grading of granite
}

\author{
J.C. Catalina Hernández y G. Fernández Ramón \\ AITEMIN, Margarita Salas, 14, Parque Leganés Tecnológico, 28918 Leganés (Madrid) \\ catalina@iies.es
}

\begin{abstract}
The production of a natural stone processing plant is subject to the intrinsic variability of the stone blocks that constitute its raw material, which may cause problems of lack of uniformity in the visual appearance of the produced material that often triggers complaints from customers.

The best way to tackle this problem is to classify the product according to its visual features, which is traditionally done by hand: an operator observes each and every piece that comes out of the production line and assigns it to the closest match among a number of predefined classes, taking into account visual features of the material such as colour, texture, grain, veins, etc. However, this manual procedure presents significant consistency problems, due to the inherent subjectivity of the classification performed by each operator, and the errors caused by their progressive fatigue.

Attempts to employ automated sorting systems like the ones used in the ceramic tile industry have not been successful, as natural stone presents much higher variability than ceramic tiles. Therefore, it has been necessary to develop classification systems specifically designed for the treatment of the visual parameters that distinguish the different types of natural stone.

This paper describes the details of a computer vision system developed by AITEMIN for the automatic classification of granite pieces according to their tone, which provides an integral solution to tone grading problems in the granite processing and marketing industry. The system has been designed to be easily trained by the end user, through the learning of the samples established as tone patterns by the user.
\end{abstract}

Keywords: computer vision, granite, natural stone, tone grading.

\section{Clasificación automática de granito según su tono}

\section{RESUMEN}

La producción de una planta de elaboración de piedra natural está sujeta a la variabilidad inherente a los bloques de piedra que constituyen su materia prima, lo que puede causar problemas de uniformidad en el material suministrado que frecuentemente ocasionan conflictos con los clientes.

La mejor forma de atajar este problema consiste en la clasificación del producto en función de sus características visuales, lo que tradicionalmente se realiza de forma manual: un operario observa cada pieza y la asigna a uno de los tipos considerados en función de parámetros visuales tales como color, textura, grano, veteado, etc. Sin embargo, esta labor presenta a su vez problemas de consistencia, debidos a la subjetividad del criterio de clasificación de cada operario, y a los errores provocados por su progresiva fatiga.

Los intentos de aplicar sistemas de inspección automática genéricos como los utilizados en la industria cerámica han resultado fallidos debido a que la piedra natural presenta una variabilidad mucho mayor que las baldosas cerámicas. Por ello, ha sido necesario desarrollar sistemas de clasificación específicamente diseñados para el tratamiento de los parámetros visuales que diferencian los distintos tipos de piedra natural.

A continuación se describe los pormenores del sistema de visión artificial desarrollado por AITEMIN para la clasificación automática de piezas de granito en función de su tono, que permite dar una solución integral a la problemática del control de tono en la industria de elaboración y comercialización de granitos. El sistema ha sido diseñado para ser entrenado fácilmente por el usuario final, mediante el aprendizaje de las muestras seleccionadas como patrones de tono.

Palabras clave: clasificación por tono, granito, piedra natural, visión artificial. 


\section{VERSION ABREVIADA EN CASTELLANO}

\section{Introducción}

El mercado de la piedra natural demanda producto con una uniformidad de características estéticas que no resulta fácil de satisfacer por los proveedores, porque la producción de una planta de elaboración está sujeta a la variabilidad natural inherente a los bloques de piedra que constituyen su materia prima. En el caso particular del granito, una variedad puede presentar ligeras variaciones en el color de los minerales o en la distribución de los granos que originan diferencias apreciables en el aspecto del material, lo que lleva a la definición de distintos tonos dentro de la variedad. Estas diferencias de tono son a menudo difíciles de distinguir a simple vista en la planta de elaboración, sobre todo cuando el material está húmedo, pero tras la instalación pueden volverse muy evidentes, originando reclamaciones de los clientes.

La clasificación de piezas de granito en función de su tono es una actividad que actualmente se realiza de forma totalmente manual, y que crea bastantes problemas por la subjetividad inherente a dicha operación. El procedimiento habitual consiste en comparar cada pieza con una serie de muestras patrón de cada uno de los tonos previamente definidos para esa variedad de granito, y asignarla al tono con el que presenta mayor parecido. Esta operación resulta un tanto subjetiva, por lo que el resultado depende de la persona que lo realiza, y puede verse influido por su nivel de fatiga o estrés, apareciendo discrepancias entre clasificaciones realizadas no sólo en distintos días, sino incluso en diferentes momentos de un mismo día.

Los intentos de aplicar sistemas de inspección automática genéricos como los utilizados en la industria cerámica han resultado fallidos debido a que la piedra natural presenta una variabilidad mucho mayor que las baldosas cerámicas. Por ello, ha sido necesario desarrollar sistemas de clasificación específicamente diseñados para el tratamiento de los parámetros visuales que diferencian los distintos tonos de una variedad de piedra natural.

\section{Objetivos}

AITEMIN ha completado con éxito un proyecto de investigación tecnológica orientado a resolver este problema, proporcionando un método automático y objetivo capaz de realizar esta clasificación mediante el uso de técnicas de visión artificial. El sistema ha sido diseñado especificamente para clasificar piezas elaboradas de granito, tales como baldosas o plaquetas, y puede adaptarse con facilidad a la problemática específica de cualquier variedad.

El funcionamiento del sistema se basa en la adquisición y procesamiento de una imagen digital en color de cada pieza que se clasifica. La imagen se captura mediante una cámara de video digital con óptica e iluminación adecuadas, y se procesa mediante un programa de ordenador que determina a cuál de los tonos patrón previamente definidos en el sistema se parece más. La definición de los tonos patrón de referencia se realiza muy fácilmente mediante una función de aprendizaje incorporada en el programa, para cuyo uso no son precisos conocimientos informáticos. De esta forma, el usuario puede modificar las clases consideradas a voluntad, para adaptarlas a los requisitos del cliente o a la evolución del material en cantera.

\section{Materiales y métodos}

Con el fin de orientar el desarrollo del proyecto hacia las necesidades reales de los productores de granito, AITEMIN se puso en contacto con varias empresas del sector de la Piedra Natural y visitó algunas plantas de elaboración, estableciendo la siguiente lista de funcionalidades deseadas, en orden de interés (pero también dificultad) creciente:

- Clasificación objetiva de piezas elaboradas secas seleccionadas a mano

- Clasificación automatizada de producto húmedo al final de la línea de elaboración

- Clasificación por tonos de material semi-elaborado

Dado que el sistema de clasificación automática debe ser capaz de reconocer los tonos de cualquier variedad de granito, se decidió basar el desarrollo en una difícil de clasificar manualmente. Para ello, se pidió a la compañía Levantina Pavimentos de Granito S.A. que proporcionara muestras de cada uno de los 17 tonos definidos en la variedad de granito "Blanco Alfa" que procesaba en su planta de Cadalso de los Vidrios (Madrid). La empresa seleccionó dos baldosas representativas de cada tono, así como dos piezas adicionales de dos de los tonos, proporcionando un total de 38 piezas. Todas ellas tenían unas dimensiones de $28 \times 28$ 
$\mathrm{cm}, 18 \mathrm{~mm}$ de espesor, y acabado pulido. El reverso presentaba el acabado semi-elaborado típico de las bandas obtenidas a partir del corte de un bloque de granito con discos diamantados.

Tras realizar diversas pruebas de captura de imágenes digitales con cámaras fotográficas y de vídeo, e investigar algoritmos de proceso que proporcionaran las capacidades deseadas, se diseñaron dos versiones del sistema: una para llevar a cabo mediciones sobre la totalidad de una pieza que se desplaza en las condiciones de una línea de elaboración, y otra como un instrumento de mano para efectuar mediciones sobre una pieza estática. Dado que ambas versiones presentan ventajas y campos de aplicación complementarios, se decidió construir un prototipo de cada una.

El primer prototipo emplea una cámara lineal en color para captar las imágenes de las piezas. Éstas se colocan sobre una plataforma acoplada a una guía lineal que las desplaza bajo la cámara a velocidad uniforme. El prototipo admite piezas de hasta $60 \times 40 \mathrm{~cm}$ de tamaño y $30 \mathrm{~mm}$ de espesor, y su diseño puede adaptarse fácilmente para su integración en una línea de elaboración. Un sistema así permitiría clasificar la totalidad de la producción a medida que circula por la línea, ya que es capaz de trabajar con material húmedo.

El segundo prototipo es una versión compacta del sistema, concebida para su uso manual. Emplea un cabezal de medición que integra una cámara de vídeo en color y un domo de iluminación difusa, que se posa sobre la pieza que se desea clasificar. Esta versión proporciona imágenes con una resolución muy superior, pero el tamaño de la zona observada es relativamente reducido, por lo que la clasificación presenta mayor variabilidad. Por dicho motivo resulta aconsejable realizar varias medidas sobre diferentes zonas de una pieza para aumentar la certidumbre de la clasificación. Un sistema así resulta adecuado para la clasificación de piezas grandes, pesadas o de forma irregular tales como tablas de granito o palés de piezas en un almacén, donde puede ser más conveniente mover el sistema de medición que el producto. También sería muy útil para caracterizar material ya instalado, a fin de determinar el tono más parecido para realizar una restauración o una ampliación.

Tras un largo esfuerzo de investigación y desarrollo, se estableció un procedimiento de proceso de imágenes que funciona bien en diferentes condiciones de la pieza (seca/húmeda, pulida/sin pulir). El procedimiento fue implantado en una aplicación informática orientada al usuario dotada de una interfaz específicamente diseñada para ser manejada por operarios sin conocimientos de informática.

\section{Resultados}

Se ha realizado un gran número de pruebas del sistema, principalmente con las 38 piezas de la variedad "Blanco Alfa", que cuenta con 17 tonos distintos y es bastante difícil de clasificar. Las pruebas se han llevado a cabo tanto con el material seco como con distintos grados de humedad.

Se ha comprobado que el sistema discrimina muy bien las piezas pulidas secas. La clasificación de piezas pulidas húmedas también ofrece muy buenos resultados, aunque la precisión obtenida es lógicamente menor que con las piezas secas. Este resultado permite considerar una aplicación muy interesante para el sistema, al poder abordar la clasificación de la producción de una línea de pulido en tiempo real sin esperar a que las piezas se sequen, con la consiguiente mejora de la calidad del control de tono y el sustancial ahorro de tiempo que se obtendría. También se han efectuado pruebas de clasificación sobre la superficie semi-elaborada de la parte trasera de las piezas húmedas, con resultados sorprendentemente buenos.

Por último, también se ha puesto a prueba la capacidad del sistema para distinguir variedades de granito mediante la realización de una prueba de clasificación sobre un conjunto de 232 imágenes de 58 piezas distintas, pertenecientes a 56 variedades de granito, la mayoría de ellas importadas, que fueron adquiridas durante la celebración de una feria del sector. La baja tasa de error obtenida demuestra que el sistema es perfectamente capaz de trabajar con variedades de granito distintas al "Blanco Alfa", y que tan sólo es necesario introducir muestras adecuadas de los tonos disponibles para que el sistema sea capaz de clasificar otras variedades.

\section{Conclusiones}

El sistema automático para clasificación por tonos de piezas elaboradas de granito descrito permite clasificar de manera objetiva y reproducible la producción de una planta de elaboración de granito, tanto si el material está seco como húmedo, y tanto si tiene un acabado pulido como si está sin pulir.

El uso de este sistema también puede mejorar la gestión de los lotes en el almacén y asegurar la concordancia de tono del material entre sucesivos envíos a un cliente, con la consiguiente reducción en las reclamaciones por parte de los clientes. 


\section{Introduction}

In the natural stone industry, the production of a processing plant is subject to the intrinsic variability of the stone blocks that constitute its raw material. This variability, which can be significant even between blocks extracted from the same zone of a quarry, may cause problems of lack of uniformity in the visual appearance of the produced material that often triggers complaints from customers. These complaints may result in the return of an entire shipment or, if the problem is discovered after the material has been installed, the application of a significant price reduction as compensation to the customer. Therefore suppliers of finished stone pieces such as tiles and slabs need to take some steps to ensure that the visual appearance of their product meets the level of uniformity required by their intended application, which is not easy to achieve in practice.

The best way to tackle this problem is to classify the produced material according to its visual features, which is traditionally done in a manual way: an operator observes each and every piece that comes out of the production line and assigns it to the predefined class most similar to it, taking into account visual features of the material such as colour, texture, grain, veins, etc. However, this manual procedure presents significant consistency problems, due to the inherent subjectivity of the classification performed by each operator, aggravated by inaccuracies caused by progressive fatigue throughout the day. As a result, there have been many attempts to develop automated classification systems that could replace the human operator in this very demanding task.

The earliest ones were mainly focused on the quality grading of marble slabs, which had a very immediate economic interest. For instance, (ClementePérez et al., 1995) describes an algorithm based on colour features and neural networks, whilst (MartínezAlajarín and Tomás-Balibrea, 1999) improved the results by introducing texture analysis with sum and difference histograms (SDH). An important milestone was the research project COSS-Characterisation of Ornamental Stones Standards by Image Analysis of Slab Surface, funded by the European Union /DGXII through its Standards, Measurements and Testing program, which was carried out between 1996 and 1998 by industrial and university teams in Portugal, Italy and Spain. (Muge et al., 1997) describes how this project focused on the development of different computer vision techniques for the characterisation and subsequent classification of four types of Italian Serizzo granite, 14 varieties of Portuguese grey granite and five classes of Spanish Macael marble.
(Ramos et al., 1999) presents the tools chosen to extract features from the Portuguese grey granites, which relate to the colour, size and spatial arrangement of the grains that constitute the granites. Achieved recognition rate was very good, but the large number of features used made training and classification quite slow and the techniques were not applied in practice. Most developments available at the time appeared promising in the laboratory, but were not yet ready for industrial application.

Later on, some companies in the natural stone sector chose to install automated visual inspection systems, derived from commercial ceramic tile inspection machines, which were expected to be able to classify tiles of sufficiently homogeneous stone types, such as some marbles and limestones. However, the results were totally unsatisfactory, and proved that generic inspection systems were not suited to the task of classifying the continuously varying colour, textures and forms of natural stone, which required the development of dedicated systems. (MartinezAlajarín et al., 2005) developed a system consisting of a mechatronic prototype to acquire images of marble slabs in suitable lighting conditions, and computational algorithms for colour texture analysis, feature reduction with principal component analysis (PCA) and a multilayer perceptron neural network, which classified slabs of a marble variety into three categories, according to their quality.

Unfortunately, the natural heterogeneity of granite prevented algorithms that performed well on marble from being successful in the classification of granite, and imposed the need to develop image features specific for this material. Besides, previous developments of granite classification systems were aimed at the recognition of granite varieties, and were not intended to discriminate between the tones of a variety, which is the real interest of granite processing plants, as they already know the varieties that they produce. Consequently, in 2005 AITEMIN considered it necessary to develop a granite classification system specially conceived for tone grading. This is the system described in (Catalina and Fernández, 2007), which was later subject to various improvements in hardware and software, as explained in (Catalina et al., 2010) and in this article.

In recent years, a number of approaches to automatic classification of samples in granite varieties have been proposed, based either on the use of spectrophotometric data or on the extraction of colour and/or texture features from images. (Araújo et al., 2010) describes a method of the first type that classifies 48 specimens with a surface area of $50 \mathrm{~cm}^{2}$ belonging to 16 varieties of granite using spectral 
reflectance data collected by a spectrophotometer, whilst (Bianconi et al., 2012) describes a method of the second type that resorts to the combined use of colour and texture features to classify 48 tiles from a group of 12 commercial classes of granite. However, to the best of our knowledge, our system remains the only one that is capable of performing tone grading by recognizing the different tones of a granite variety.

\section{Tone grading}

A commercial variety of granite typically presents subtle variations in the colour of minerals or in its grain distribution that cause perceptible differences in the appearance of the material, leading to the definition of distinct tones in the variety. These tone differences are almost undistinguishable to the naked eye when the wet finished product leaves the production line, but they become apparent once it is dry. The tone consistency problem typically occurs when tiles from different tones are mixed in an installation: while the material is wet, it looks good, but some days later, when it gets dry, the mix of tones becomes evident and the customer complains. The problem is even more serious when the material is used in the repair or extension of previous works, when a perfect match of tone is imperative.

The sorting of granite tiles according to their tone ('tone grading') is an activity currently performed in a totally manual way, and is subject to many practical difficulties. The usual procedure is to compare the piece to sort (once it is completely dry) with a series of "tone standard" pieces representing the tones previously defined for that specific granite variety, and assign it to the closest tone. This operation is very subjective, and therefore its outcome depends on the person performing it, and may be influenced by his level of fatigue or stress. As a result, discrepancies may appear between classifications made not only on different days, but even at different times of the same day, greatly diminishing the effectiveness of the sorting process.

\section{Objectives}

AITEMIN decided to carry out a technology research project aimed at solving the problem described above by developing an automated and objective method to perform this classification by means of artificial vision techniques. The system was initially conceived to process granite pieces such as tiles or slabs with a polished finish, and had to be easily adapted to the particular characteristics of any granite variety.

In order to know in detail the needs of granite producers and steer the project accordingly, AITEMIN contacted some companies in the Natural Stone sector and visited a few processing plants. One of them was the plant that the company "Levantina Pavimentos de Granito, S.A." has in Cadalso de los Vidrios (Madrid), which produces tiles of a number of granite varieties. The technical management of the plant kindly explained to us the operation of the plant and the classification procedure they had in place, and even their "wish list" to improve it.

In order of increasing interest, the desired technologies were:

- objective tone grading of manually-fed dry polished samples

- automated in-line sorting of the wet polished product at the end of the processing line

- effective tone grading of the semi-finished material in stock

Unfortunately, their implementation complexity also seemed to increase with their interest, so it was decided to address the easiest challenge first, and tackle the remaining challenges only after the performance of the system on the polished product was successful.

\section{Methodology}

Although the Cadalso plant produced granite varieties comprising very few tones that were easier to classify, we considered that the automatic classification system would only prove its effectiveness by correctly recognizing every tone in problematical varieties. Therefore, we asked the company to provide us with a representative sample of each of the tones defined in their most complicated variety.

The company kindly agreed to select and supply two representative tiles of each of the 17 tones that had been defined in their "Blanco Alfa" variety, a quite light grey granite. Four tiles were provided from two of the tones, making a total of 38 tiles. Images of tones 701 to 709 are shown in Figure 1 and images of tones 711 to 802 are shown in Figure 2. All the tiles were sized $28 \times 28 \mathrm{~cm}, 18 \mathrm{~mm}$ thick, polished on one side, and labelled on the edge. The reverse side had the smooth semi-finished surface of the bands produced by the cutting of granite blocks with diamond saw blades, so as a result we had samples of both types of finishing for our tests.

The proposed automated tone grading method is 

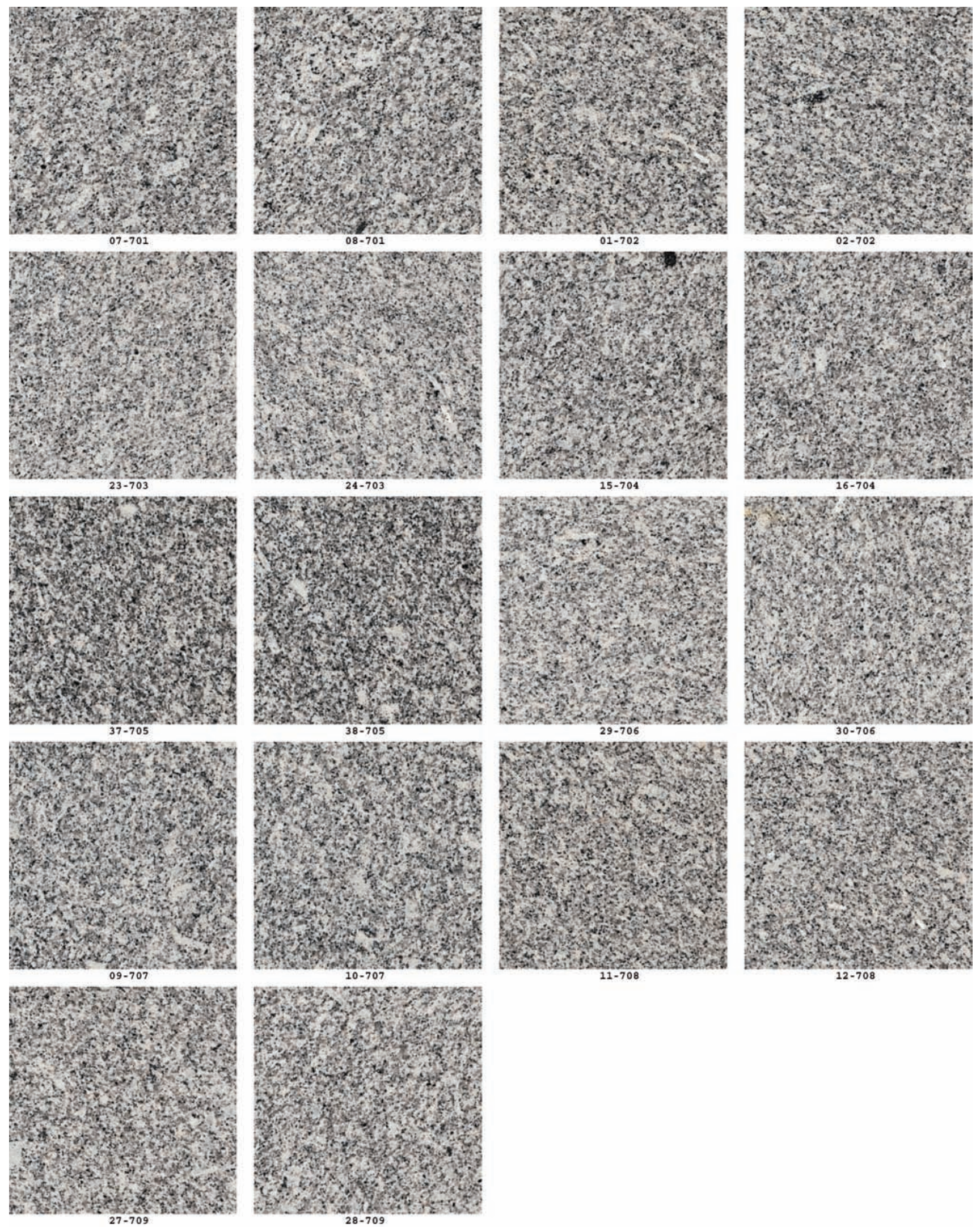

Figure 1. Images of dry "Blanco Alfa" tiles of tones 701 to 709 - Labels: Tile number - Tone reference.

Figura 1. Imágenes de baldosas secas de "Blanco Alfa" de los tonos 701 al 709 - Rótulos: Núm. de baldosa - Tono. 

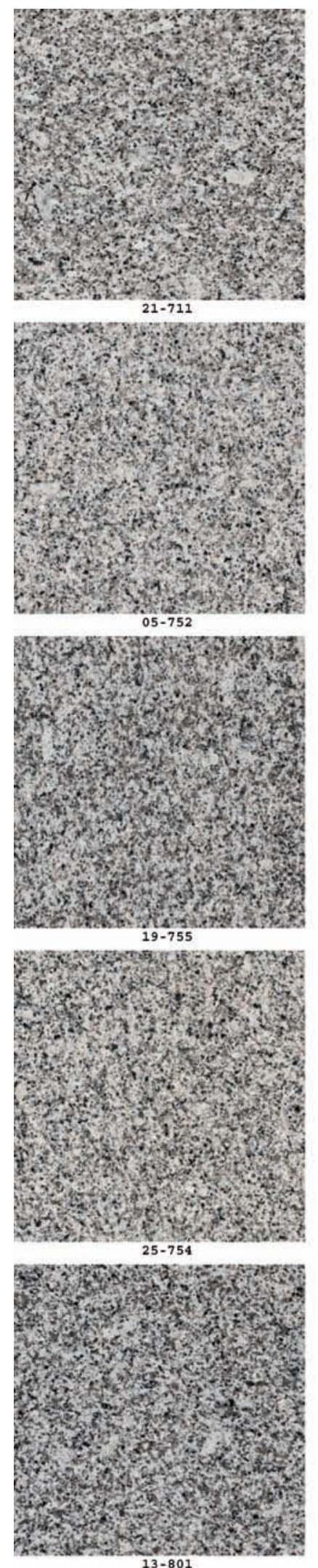
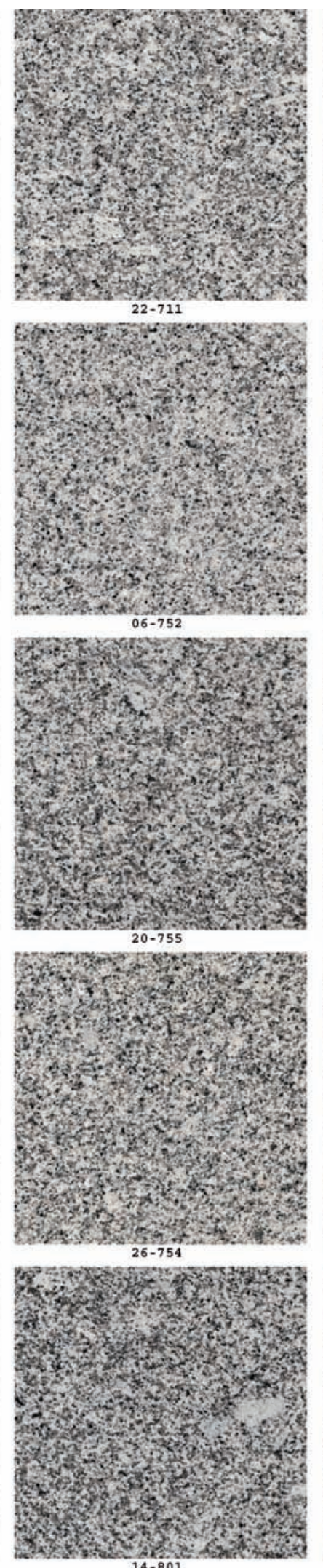
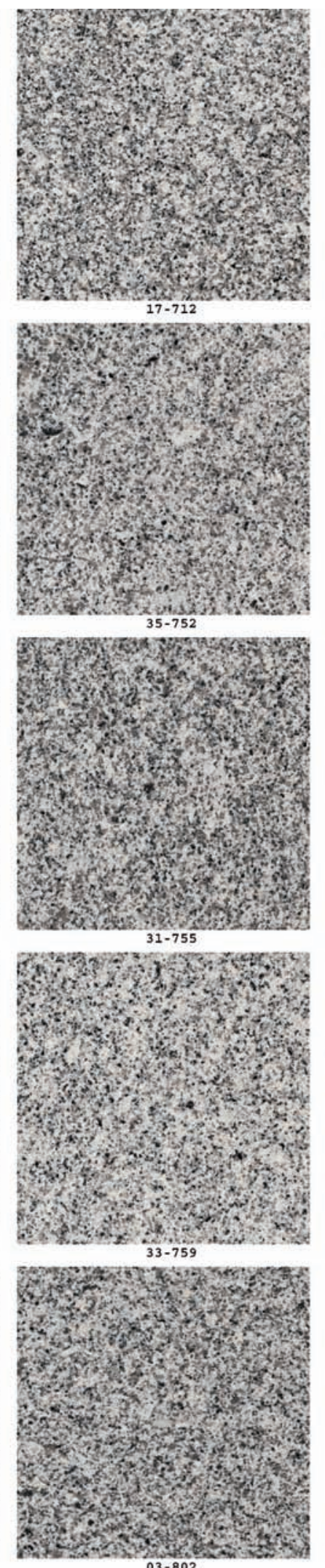
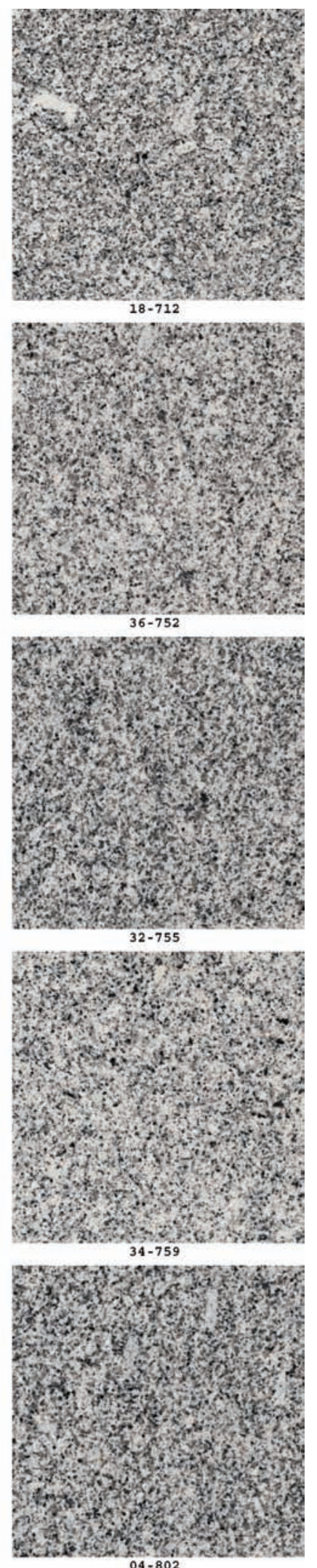

Figure 2. Images of dry "Blanco Alfa" tiles of tones 711 to 802 - Labels: Tile number - Tone reference.

Figura 2. Imágenes de baldosas secas de "Blanco Alfa" de los tonos 711 al 802 - Rótulos: Núm. de baldosa -Tono. 
based on the acquisition and subsequent processing of digital colour images of the pieces that are to be classified. The images are captured using a digital colour video camera with appropriate optics and illumination, and a computer processes the obtained images through specially developed software that determines automatically which of the predefined tones is the closest to each piece (Fig. 3).

The management of reference tones for each variety is easily done by the operator through a training procedure built-in into the software, whose use is very intuitive and requires no computer knowledge (Fig. 4). Therefore, it is straightforward to modify the classification criteria when necessary, adapting them to customer requirements or to the evolution of the material in the quarry. Moreover, the system can indicate when a material is too different from the preset tones, and when it could therefore be appropriate to set a new tone.

\section{Prototypes}

The tiles were initially pictured in the lab with both photographic and video cameras, to establish image acquisition requirements in terms of resolution and lighting, and to investigate suitable image processing algorithms. Taking into account these requirements and the desired capabilities, two different versions of the system were designed: one to perform full-piece measurements on moving tiles in the conditions of a processing line, and the other as a manual instrument to measure small areas on static tiles. As both versions had complementary fields of application and strengths, one prototype of each was built.

The first prototype (Fig. 5) is based on a colour line scan camera that captures the full width of tiles passing underneath it. Tiles to be processed are laid on a plate that travels at a uniform velocity by means of a linear motion system, to reproduce the conditions of a granite processing line. Tile images are composed by the juxtaposition of the lines captured by the camera as the tiles move underneath. The design of the prototype allows the processing of tiles up to $60 \times 40$ $\mathrm{cm}$ in size, and up to $30 \mathrm{~mm}$ thick. As it is just a demonstrator for the proposed principle of operation, the tiles have to be loaded and unloaded manually.

Nevertheless, this design can be easily adapted for integration in a continuous production line by mounting the image acquisition components (camera and lighting) at an appropriate point of the processing line. Both elements would have to be protected from

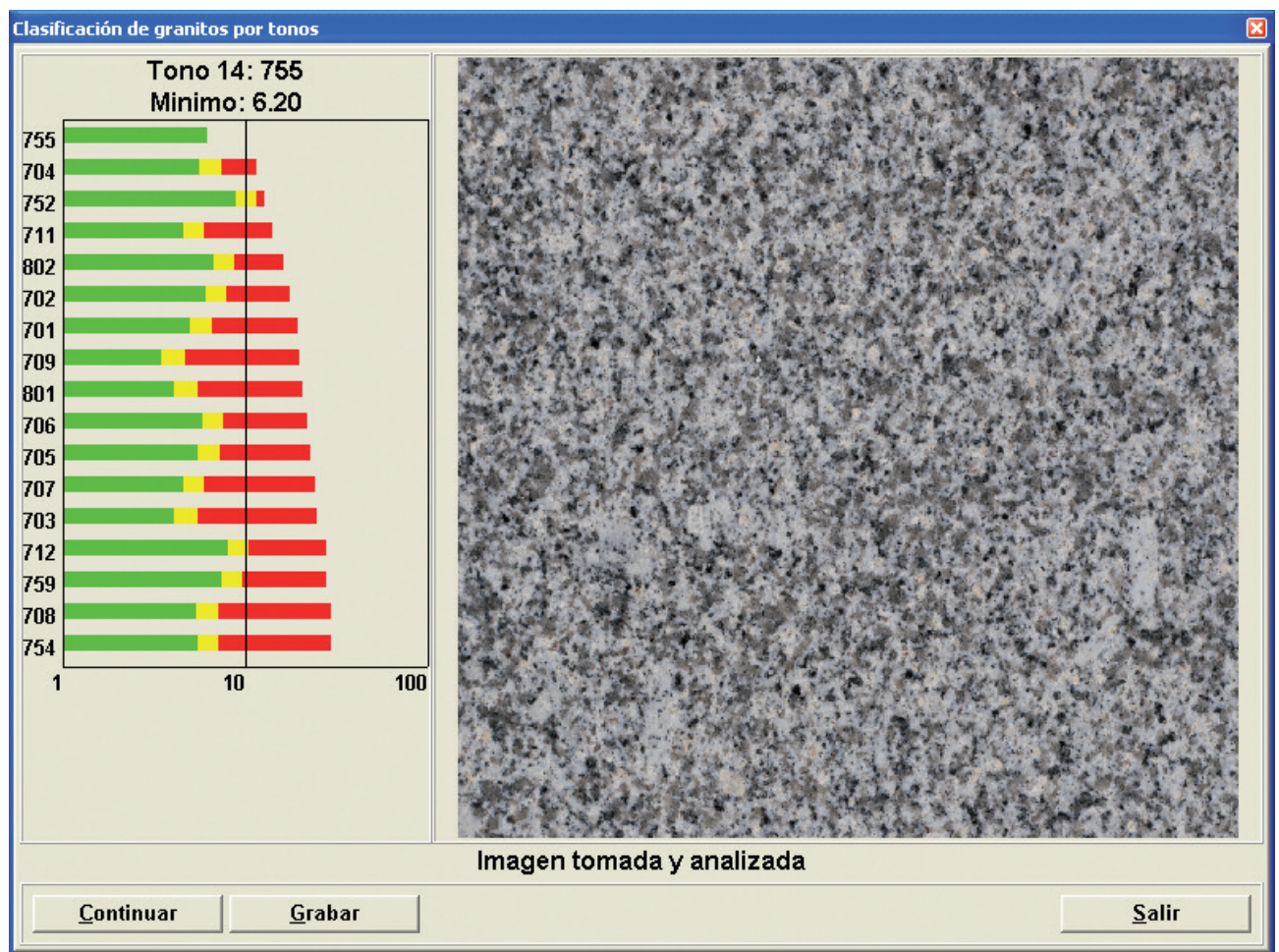

Figure 3. Results of a tile classification.

Figura 3. Resultado de la clasificación de una baldosa. 


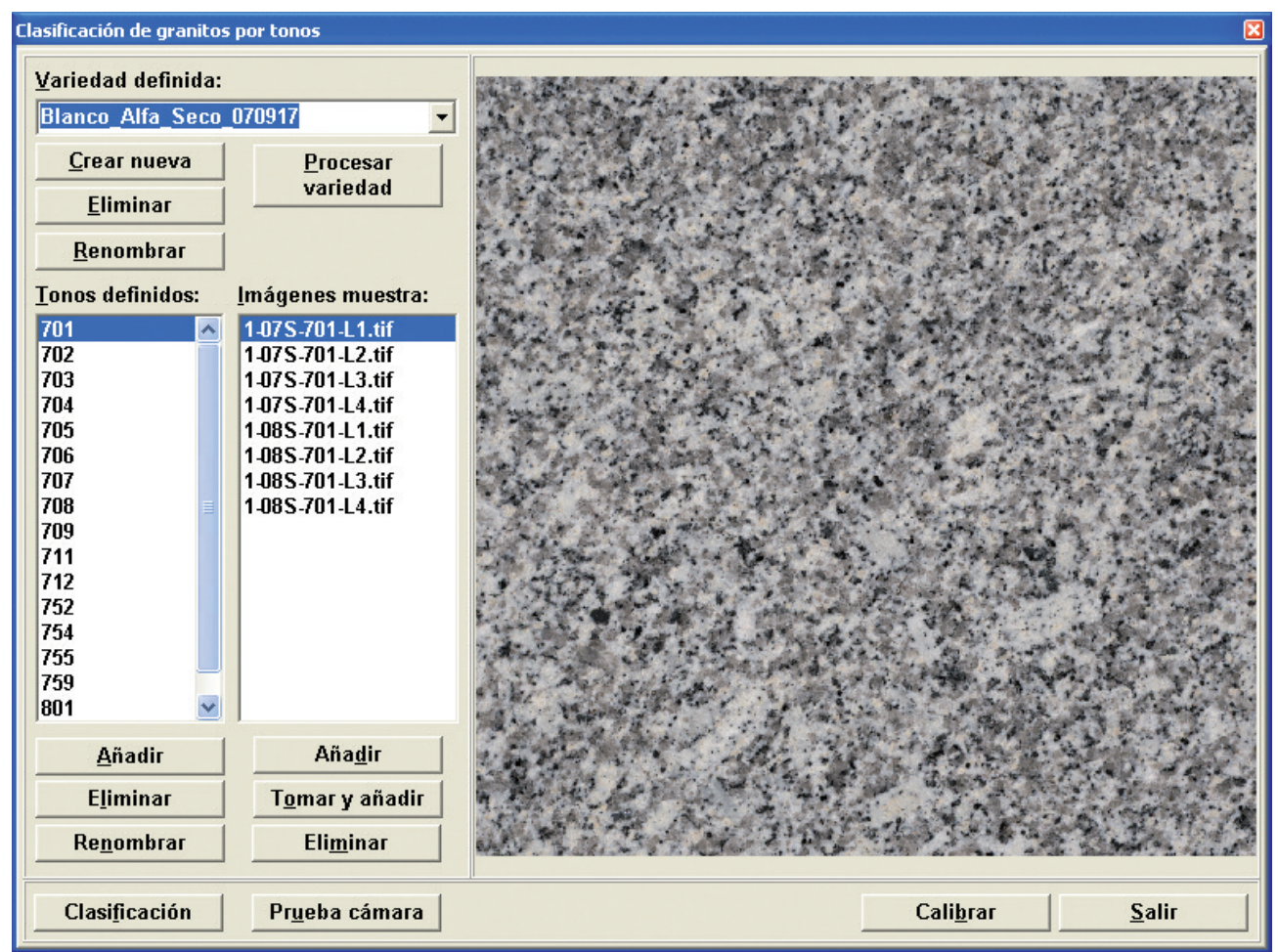

Figure 4. Variety and tone management interface.

Figura 4. Interfaz para gestión de variedades y tonos.

the harsh environmental conditions (water, vibrations, etc ...) of the line, but this should not pose any extraordinary problems. Such a setup would classify the entire production as it flows through the line, because the system is capable of working with wet material. The system could be programmed to alert the operator of a change of tone, or to mark each piece according to its tone, or even to activate a line actuator to divert tiles according to the classification criteria.

The second prototype is a simplified and much more compact version of the system, intended for manual use. It is based on a mobile measurement head assembly incorporating a colour video camera and a diffuse lighting dome, which is simply deposited on the piece to be classified (Fig. 6). It can be made fully portable quite easily, by just adding a battery to feed the lighting and using a wearable or laptop computer. This prototype provides very detailed images with a resolution more than three times higher than the other version of the system, however the size of the captured area $(100 \times 75 \mathrm{~mm})$ is much smaller, so classification results have an intrinsically higher variability. It is therefore advisable to perform several measurements on different areas of a piece to increase the confidence of the results.
This version of the system is very convenient for the classification of large, heavy or irregularly shaped pieces, such as palletised stock in a warehouse, where it could be easier to move the measuring station from pallet to pallet than to transfer the product to a fixed measuring station. Another very interesting application would be the characterisation of already installed material, in order to determine the closest available tone to perform a restoration.

In both prototypes, the most critical element is the lighting, which has to be as uniform and stable as possible to provide repeatable results. Moreover, a system calibration procedure included in the software application is essential to guarantee the objectivity and reproducibility of the results along time and across different systems.

\section{Procedure}

As explained by the technical management of the Cadalso plant, the key to a successful grading of granite tone lies in the analysis of colour differences between the sample and the tone standard for each of the minerals that constitute granite, not in the study of differences in size or distribution of mineral grains. 


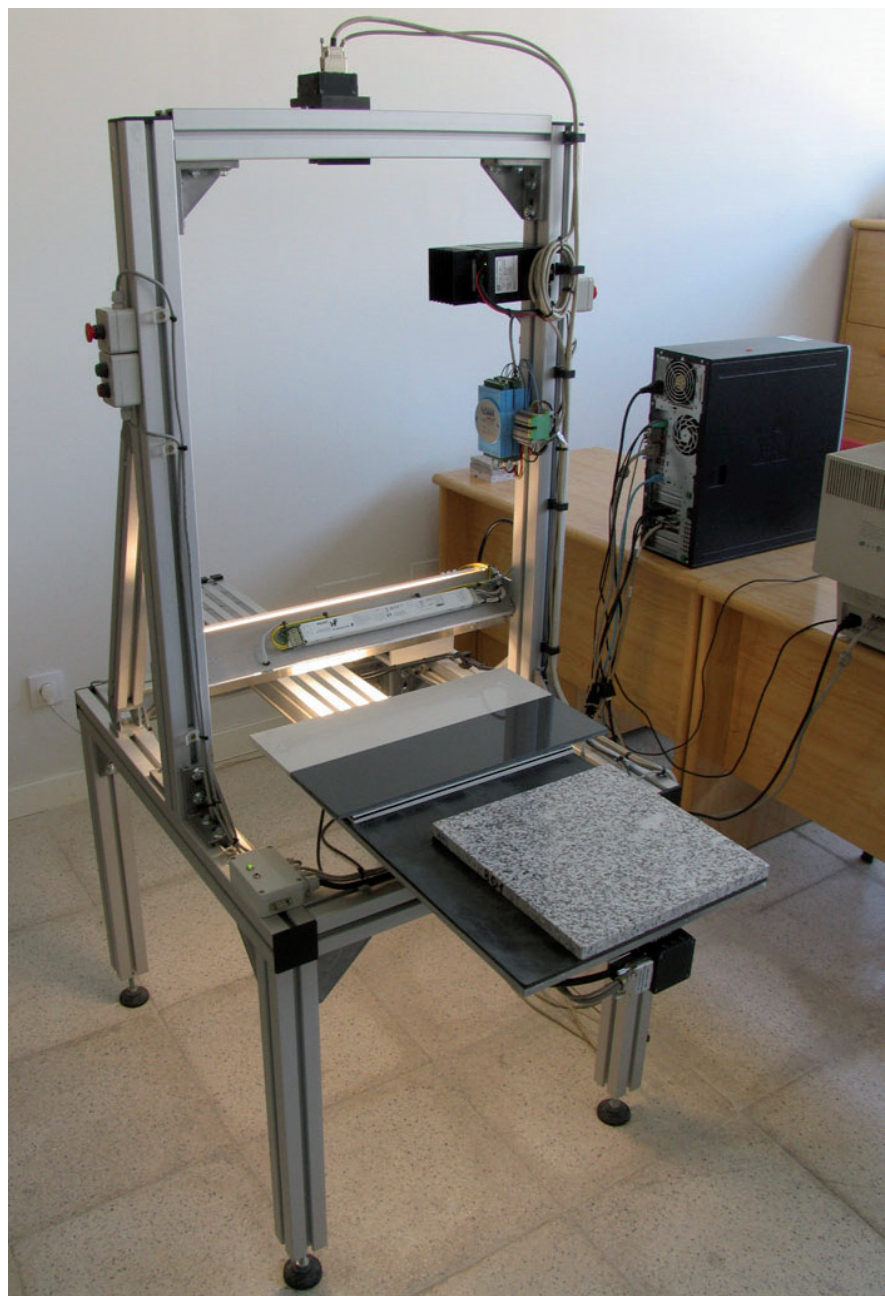

Figure 5. View of an in-line classification prototype.

Figura 5. Vista del prototipo para clasificación en línea.

Consequently, it is much more a problem of colour analysis than of texture analysis.

These colour differences are typically subtle, and for this reason it is better to measure them by looking at the minerals one by one than by trying to determine them all simultaneously from a global colour comparison of the whole tile. However, what is easy to do for a human brain is not so easy to implement in a computing program, and therefore we had to dedicate a substantial effort to establish a suitable procedure to perform it. After extensive research, an image processing procedure was established that provided excellent results on dry polished tiles and slabs, and very good results on wet pieces, either polished or semi-finished.

The procedure starts with the conversion of the colour image of the piece from the RGB colour space to the CIE $1976\left(L^{*} a^{*} b^{*}\right)$ colour space, applying for-

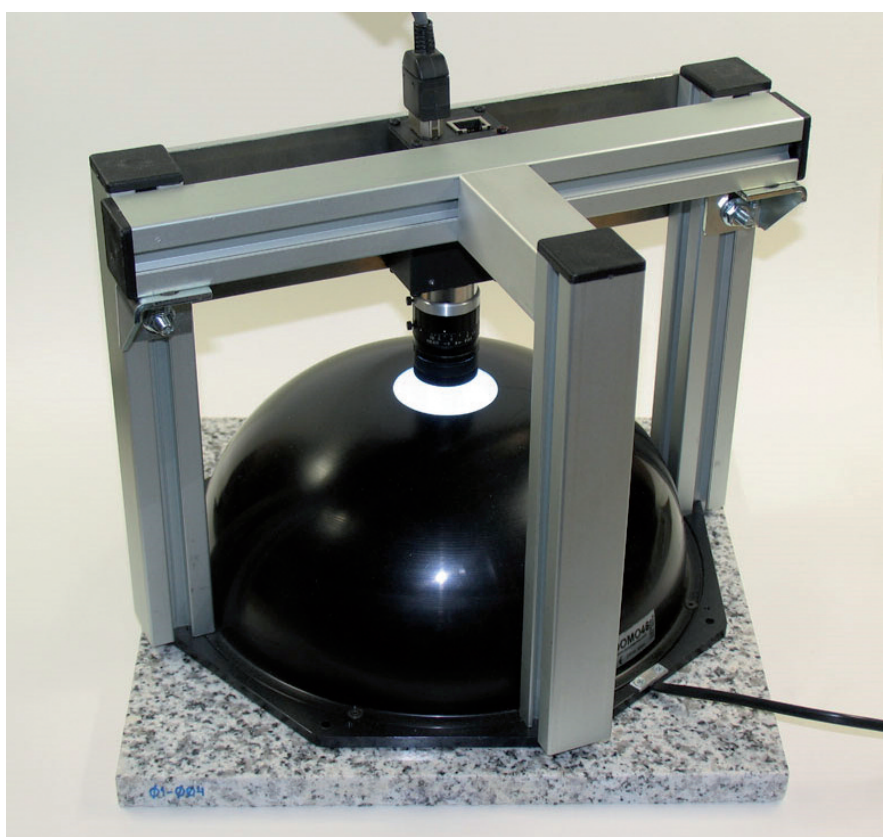

Figure 6. View of a static measuring head prototype.

Figura 6. Vista del prototipo de cabezal para medida estática.

mulae from (International Commission on Illumination, 2007). The main advantage of this transformation is that the $L^{*} a^{*} b^{*}$ colour space is perceptually uniform, which means that changes of the same amount in a colour value should produce changes of about the same visual importance. Then, the pixels of the image are distributed in $\mathrm{N}$ bins, each one collecting the pixels belonging to a particular fraction of the minerals. For each of the bins, average values and standard deviations of $a^{*}, b^{*}$ and $Y$ (luminance) coordinates as well as covariance between $a^{*}$ and $b^{*}$ are computed, as prospective image features to carry out the training and classification process. Hence, an image is represented by a vector of (variables $\times$ bins) features, that is, $7 \mathrm{~N}$ features:

$$
\begin{gathered}
x=\left[a_{1}, \ldots a_{N}, \sigma_{a 11}, \ldots \sigma_{a N}, b_{1}, \ldots b_{N}, \sigma_{b 1}, \ldots \sigma_{b N},\right. \\
\left.c_{1}, \ldots c_{N}, Y_{1}, \ldots Y_{N}, \sigma_{Y 1}, \ldots \sigma_{Y N}\right]
\end{gathered}
$$

The classifier selected for the system is minimum Mahalanobis distance, which is a classical technique suitable for highly correlated features like the ones described above, but with moderate computing power requirements. We classify a feature vector $x$ by computing the Mahalanobis distance from $x$ to each of the means, and assigning $x$ to the class for which Mahalanobis distance is minimum. The squared Mahalanobis distance $d^{2}$ of vector $x$ to class $i$ is computed as: 


$$
d^{2}=\left(x-\mu_{i}\right)^{T} C_{i}^{-1}\left(x-\mu_{i}\right)
$$

where

$\mu_{i}$ is the mean vector of class $i$

$C_{i}^{-1}$ is the inverse of the covariance matrix of class $i$

The main advantage of this classifier is that the learning process only affects the class to which vectors are added/removed, so it is quite straightforward (and fast) to retrain the classifier after the addition of new tone standards. In order to train class $i$, it is sufficient to compute the mean vector $\mu_{i}$ and the inverse of its covariance matrix $C_{i}^{-1}$.

As the number of features can be very high, tests were made to check if the application of PCA was a feasible way to reduce the number of features while maintaining the effectiveness of the classification. Results showed that 16 principal components were equivalent to the whole set of $7 \mathrm{~N}$ features, and that 9 principal components were sufficient in most cases. Tests were also carried out to determine how many bins were necessary, which of the seven variables were really significant and contributed to the classification, and which ones were redundant. Classification results showed that average values of $a^{*}, b^{*}$ and $Y$ over nine bins were sufficient to achieve a successful tone grading on "Blanco Alfa" granite, and that standard deviations of $a^{*}, b^{*}$ and $Y$ and covariance of $a^{*}$ and $b^{*}$ could be spared. However, it was decided to keep the source code unaltered, and select the bins and variables to be used through an initialisation parameters file, just in case some granite variety might be found in the future that required the use of more bins or of any of those variables to achieve a good classification performance.

The processing procedure was originally implemented in a research-oriented software application that allowed the user to define diverse varieties, to manage the tile images that typify the tones in each variety, to train the system on those images, to run classification tests on different samples, and to depict samples and results both graphically and numerically in order to better analyse them (Figs. 7 to 10 and 13 show screen captures of this program).

However, although this application was very helpful for the tuning of the self-learning algorithms, it was deemed too complex for daily system operation. Therefore, a user-oriented software application was later developed, incorporating a streamlined interface specifically designed for operators with no computer skills. Figures 3 and 4 are in fact screen captures of this application.

\section{Results}

A large number of tests were done with the system, mainly with the 38 tiles of the variety "Blanco Alfa", which has 17 distinct tones and is a priori one of the most difficult to differentiate.

It was found that the system performed extremely well in the discrimination of dry polished tiles. Figure 7 shows perfect results in a classification test on a set of 152 samples (four images from each tile) after

\begin{tabular}{|c|c|c|c|c|c|c|c|c|c|c|c|c|c|c|}
\hline \multicolumn{13}{|c|}{ Matriz de confusión } & \multicolumn{2}{|c|}{ - } \\
\hline & \multicolumn{7}{|c|}{ Variedad } & \multicolumn{7}{|c|}{ Prueba } \\
\hline & & \multicolumn{3}{|c|}{ Porvariables } & \multicolumn{3}{|c|}{ Por comp. princ. } & \multicolumn{4}{|c|}{ Porvariables } & \multicolumn{3}{|c|}{ Por comp. princ. } \\
\hline & № & Err. & & ondad & Err. & $\%$ & ndad & № & Err. & & ondad & Err. & & ondad \\
\hline 701 & 8 & 0 & 0,0 & 0,64 & 0 & 0,0 & 0,79 & 8 & 0 & 0,0 & 0,43 & 0 & 0,0 & 0,90 \\
\hline 702 & 8 & 0 & 0,0 & 1,00 & 0 & 0,0 & 1,53 & 8 & 0 & 0,0 & 0,47 & 0 & 0,0 & 0,90 \\
\hline 703 & 8 & 0 & 0,0 & 1,51 & 0 & 0,0 & 3,80 & 8 & 0 & 0,0 & 1.26 & 0 & 0,0 & 3.26 \\
\hline 704 & 8 & 0 & 0,0 & 0,69 & 0 & 0.0 & 0,72 & 8 & 0 & 0.0 & 0,37 & 0 & 0.0 & 0.46 \\
\hline 705 & 8 & 0 & 0,0 & 1,89 & 0 & 0,0 & 2,85 & 8 & 0 & 0.0 & 1.12 & 0 & 0,0 & 1,80 \\
\hline 706 & 8 & 0 & 0,0 & 1.19 & 0 & 0.0 & 1,40 & 8 & 0 & 0.0 & 1,23 & 0 & 0.0 & 1.59 \\
\hline 707 & 8 & 0 & 0,0 & 1.45 & 0 & 0,0 & 2,81 & 8 & 0 & 0.0 & 0,92 & 0 & 0,0 & 1,93 \\
\hline 708 & 8 & 0 & 0,0 & 0,92 & 0 & 0,0 & 1,12 & 8 & 0 & 0,0 & 0.74 & 0 & 0,0 & 1,02 \\
\hline 709 & 8 & 0 & 0,0 & 1,31 & 0 & 0,0 & 1,53 & 8 & 0 & 0,0 & 1,30 & 0 & 0,0 & 1,50 \\
\hline 711 & 8 & 0 & 0,0 & 0,69 & 0 & 0,0 & 1,34 & 8 & 0 & 0,0 & 0,52 & 0 & 0,0 & 1,03 \\
\hline 712 & 8 & 0 & 0,0 & 1.43 & 0 & 0,0 & 2,01 & 8 & 0 & 0.0 & 1.03 & 0 & 0,0 & 1,78 \\
\hline 752 & 16 & 0 & 0,0 & 0,61 & 0 & 0,0 & 0,90 & 16 & 0 & 0,0 & 0.47 & 0 & 0,0 & 0,71 \\
\hline 754 & 8 & 0 & 0,0 & 1,42 & 0 & 0,0 & 2,12 & 8 & 0 & 0,0 & 1,50 & 0 & 0,0 & 2.43 \\
\hline 755 & 16 & 0 & 0,0 & 0,63 & 0 & 0,0 & 0.94 & 16 & 0 & 0,0 & 0,57 & 0 & 0.0 & 0.94 \\
\hline 759 & 8 & 0 & 0,0 & 1,31 & 0 & 0,0 & 2,10 & 8 & 0 & 0.0 & 1,31 & 0 & 0,0 & 1,92 \\
\hline 801 & 8 & 0 & 0,0 & 1.45 & 0 & 0,0 & 3.61 & 8 & 0 & 0.0 & 1.09 & 0 & 0,0 & 2,31 \\
\hline 802 & 8 & 0 & 0,0 & 1,25 & 0 & 0,0 & 1,43 & 8 & 0 & 0.0 & 0,81 & 0 & 0.0 & 0,91 \\
\hline \multirow[t]{2}{*}{ Totales } & 152 & 0 & 0,0 & 1.01 & 0 & 0,0 & 1,52 & 152 & 0 & 0,0 & 0.77 & 0 & 0,0 & 1.26 \\
\hline & & & & & & & & & & & & & \multicolumn{2}{|c|}{ Grabar } \\
\hline
\end{tabular}

Figure 7. Results of a test on dry "Blanco Alfa" tiles.

Figura 7. Resultados de un ensayo procesando baldosas secas de la variedad "Blanco Alfa".

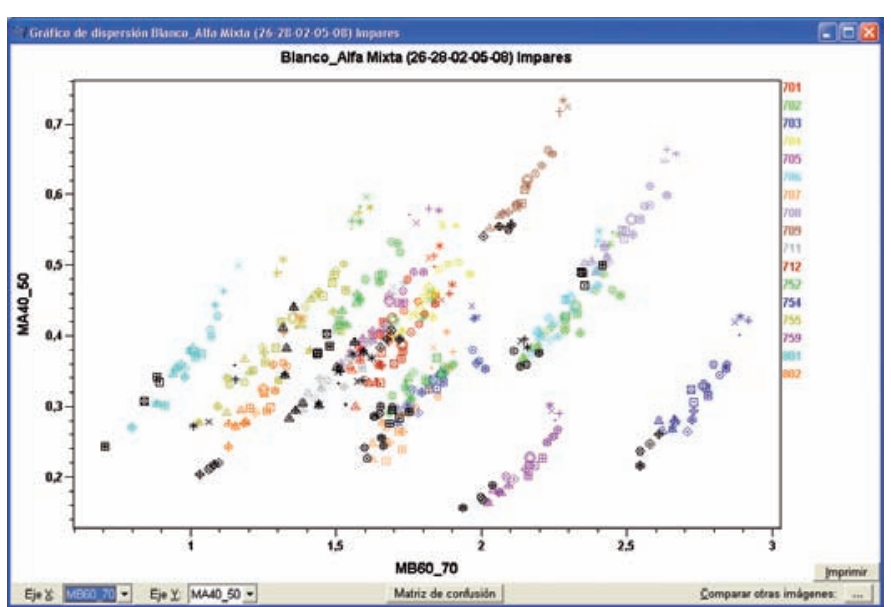

Figure 8. Evolution of "Blanco Alfa" tiles with immersion time: 0, 2, 4, 7, 10 and (in black) 13 days.

Figura 8. Evolución de las baldosas "Blanco Alfa" con el tiempo de inmersión: 0, 2, 4, 7, 10 y (en negro) 13 días. 


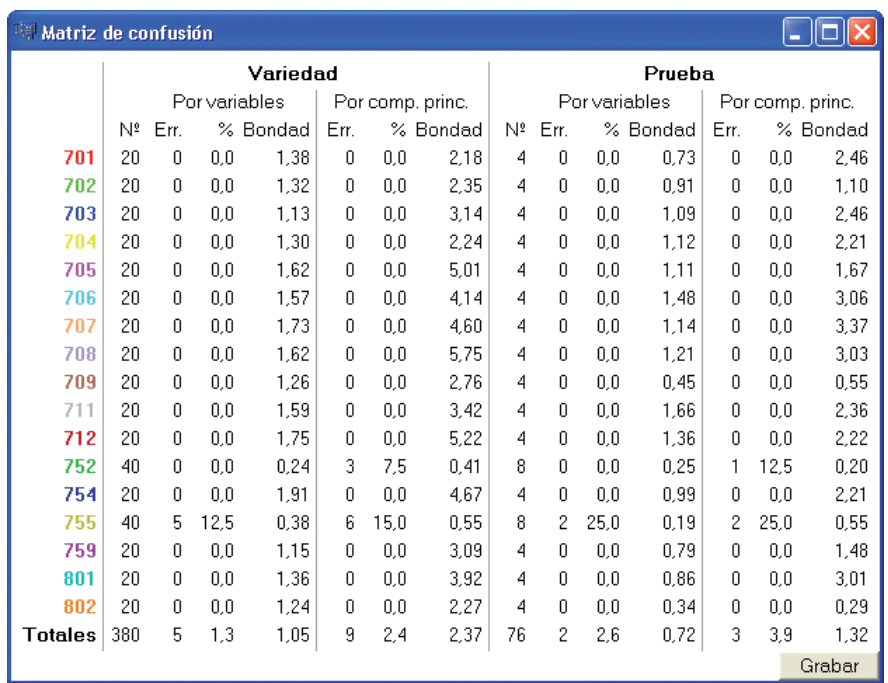

Figure 9. Results of a test on wet "Blanco Alfa" tiles.

Figura 9. Resultados de un ensayo procesando baldosas húmedas de la variedad "Blanco Alfa".

training the system on a set of 152 samples acquired on another day.

As the results of the classification of polished pieces were so good, and there was nothing in the procedure that prevented it from working on wet samples, we decided to give it a try. The resulting classification of wet polished pieces was also very good, although accuracy was understandably lower than on dry pieces. In this case, we realised that it was better to train the system with tiles that were in the same wetness conditions as the pieces to classify, as time spent immersed in water has a substantial influence on the appearance of granite. Figure 8 illustrates the evolution of tiles with immersion time for $0,2,4$, 7, 10 and 13 days whilst Figure 9 shows a $2.6 \%$ error in the results of a classification test carried out on a set of 76 13-days samples after training the system on a set of $380(0,2,4,7$ and 10-days) samples.

This result opens up a very interesting implementation of the system, since it enables the possibility of addressing the classification of the production of a polishing line in real time without waiting for the pieces to dry, with the consequent increase of tone control quality and the significant time savings it represents.

Tests were also done on semi-finished pieces, with surprisingly good results. Initially, the main problem was that the unpolished surface did not allow the visualization of the true colour of the minerals. The material appeared whitish and lacking contrast to the eye, so it seemed unlikely that a camera could extract more information. However, the appearance of the

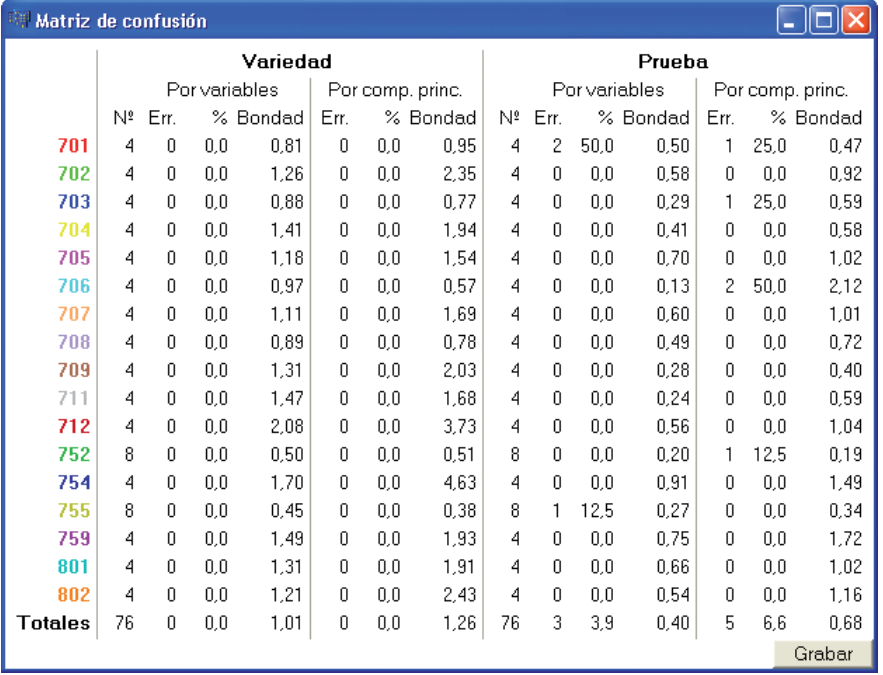

Figure 10. Results of a test on the reverse of wet "Blanco Alfa" tiles. Figura 10. Resultados de un ensayo procesando el reverso de baldosas húmedas de la variedad "Blanco Alfa".

material changes drastically when wet, showing much more contrast. For this reason it was decided to tackle the problem through the acquisition of images of wet samples. Figure 10 shows a $3.9 \%$ error in a classification test carried out on a set of 76 images of the reverse of the tiles after a 1-day immersion period. Training of the system was done on a different set of 76 images of the reverse of the tiles.

And finally, although it was not one of the original objectives of the project, it was decided to test the system's ability to distinguish among different granite varieties. Its performance was checked by performing a training and classification test on a set of 232 images belonging to 56 varieties of granite, most of them imported, which were acquired from 58 pieces that were temporarily borrowed from the Levantina stand during the Piedra 2006 trade fair. Images of these varieties are shown in Figure 11 and Figure 12.

The low error rate in this classification $(1.3 \%$, as shown in Fig.13) proves that the system is perfectly capable of working with granite varieties different to "Blanco Alfa", and it is only necessary to introduce proper samples of the available tones for the system to be able to classify new varieties.

\section{Conclusions}

The automated tone grading system of finished granite pieces described in this article has demonstrated in laboratory tests that it is capable of classifying in an objective and reproducible way the production of 

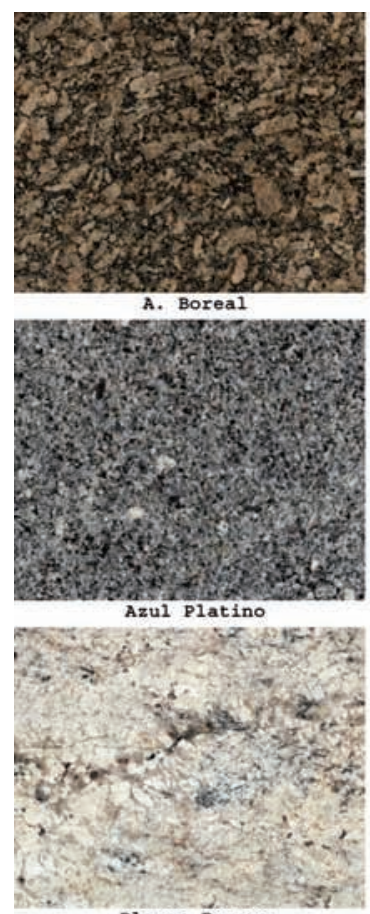

Blanco Romano

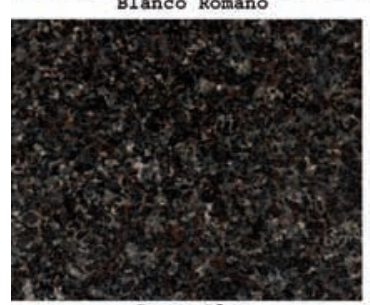

Cacao Blue
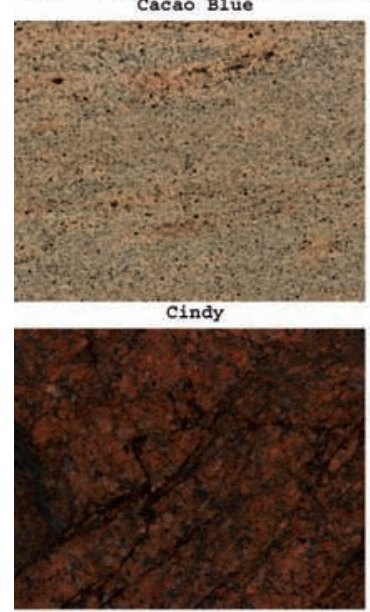

Dragon Red

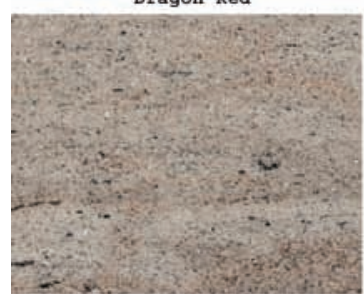

Ghibli
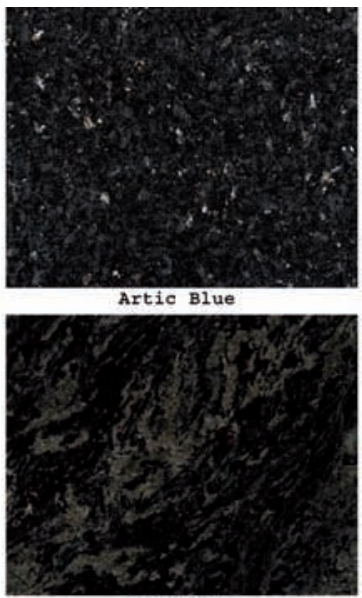

Barracuda

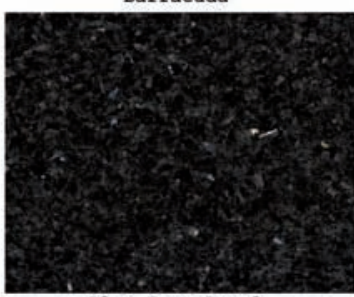

Blue Eyes Pear1

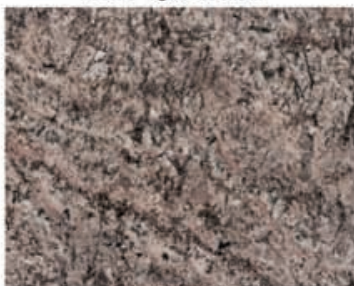

Came 1 Suede

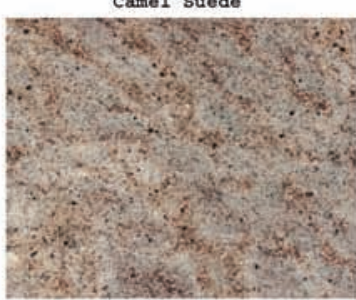

Cinnamon

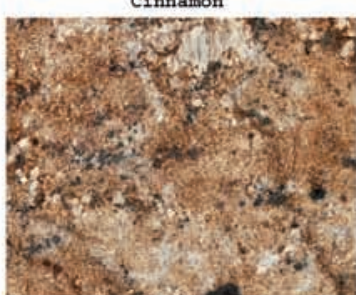

Ebb Tide

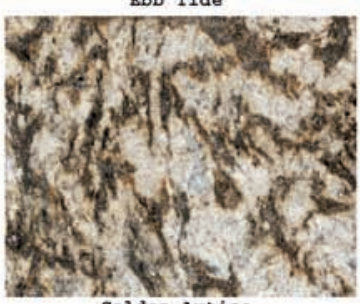

Golden Artico

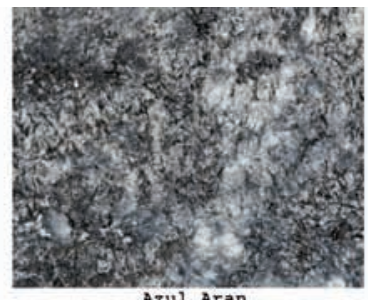

Azul Aran
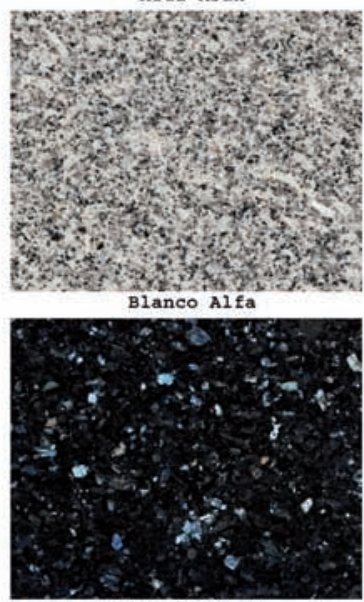

Blue Pearl GT

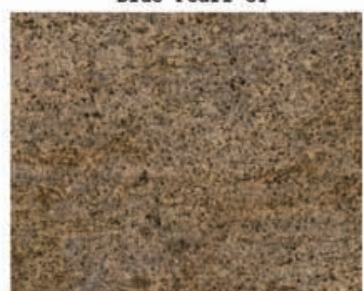

Canary

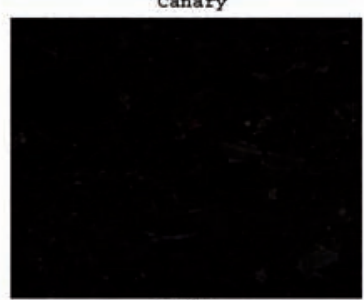

Cohitba

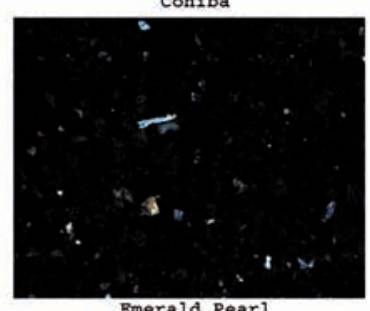

Emerald Pear

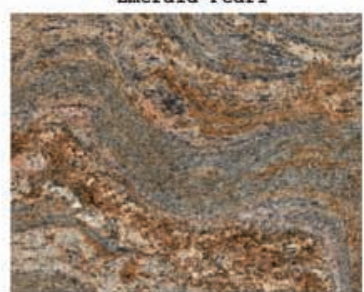

Golden Colombo

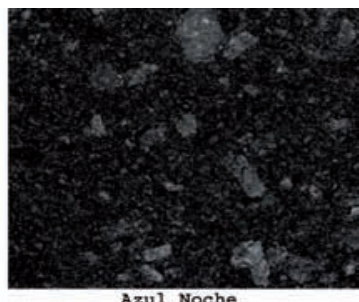

Azul Noche

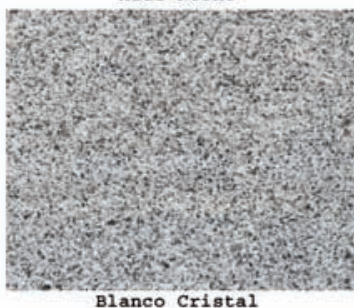

Blanco Cristal

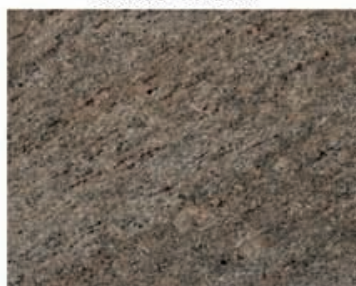

Brazilian Viara

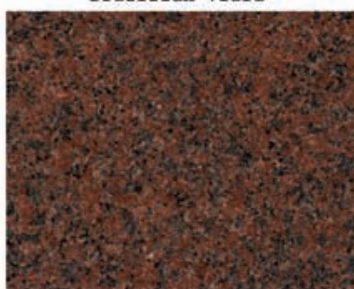

Capao Bonito
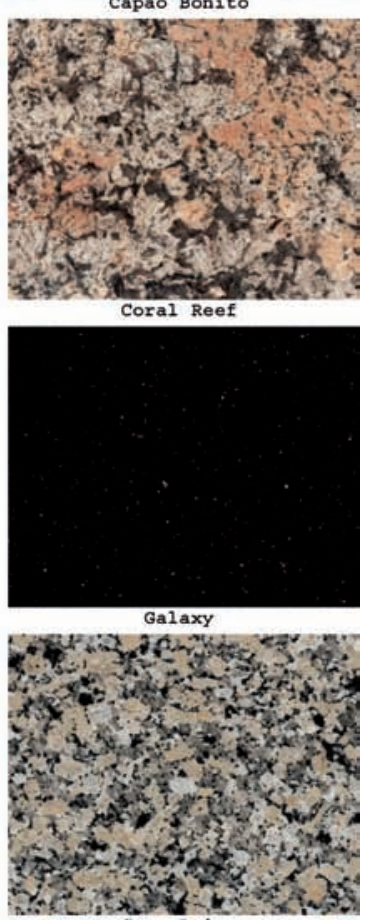

Gran Beige

Figure 11. Images of different granite varieties used in the tests.

Figura 11. Imágenes de diferentes variedades de granito empleadas en las pruebas. 

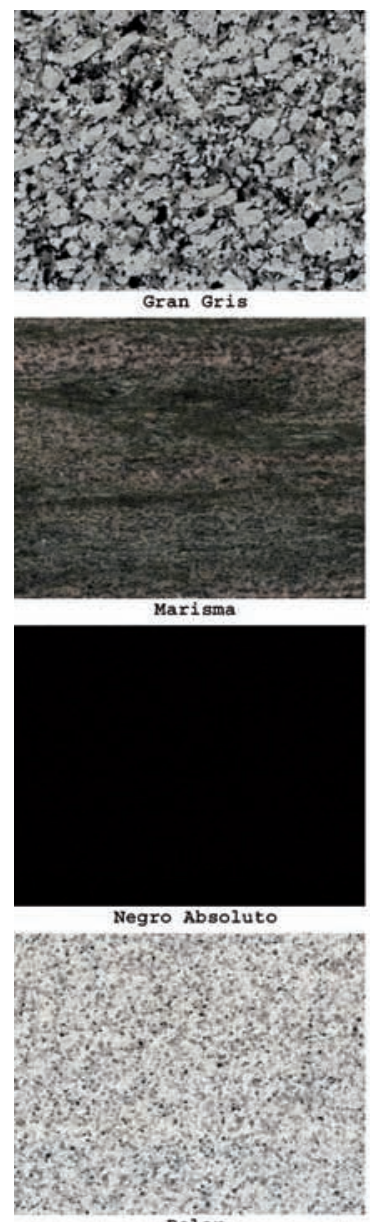

polar

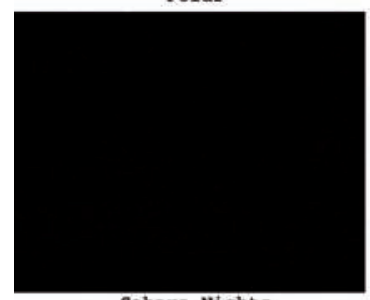

Sahara Nights

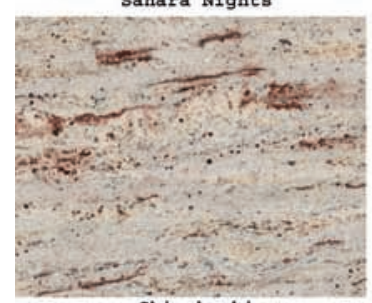

shivakashi

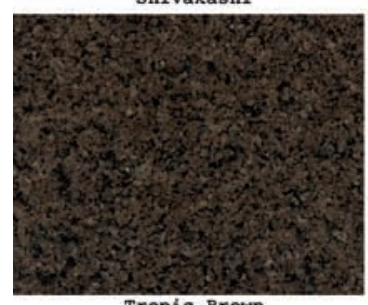

Tropic Brown

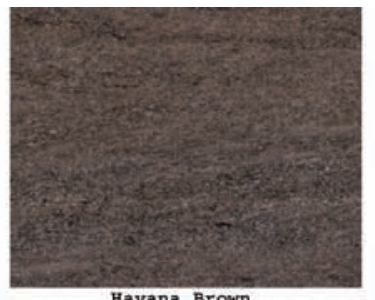

Havana Brown

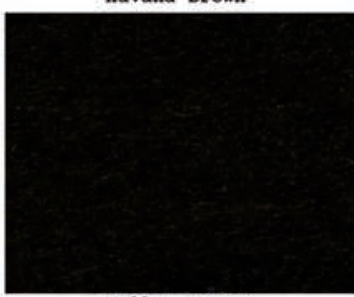

Mellow Brown

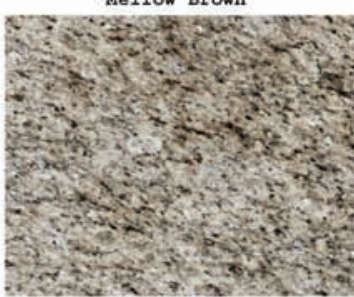

Ornamental

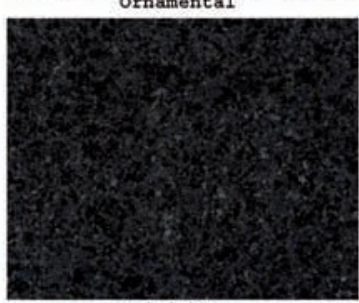

Quati Blue

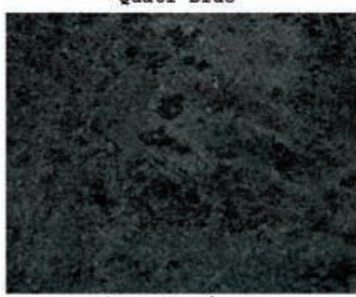

San Francisco

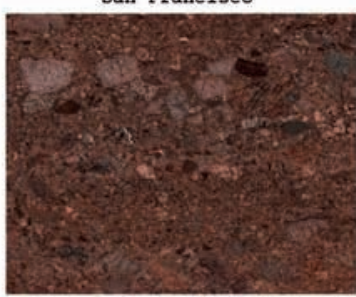

Terracota

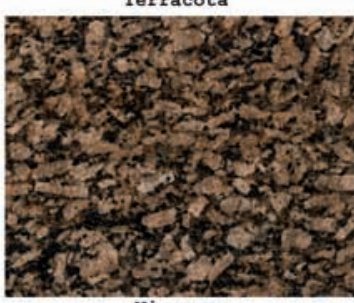

vicenza

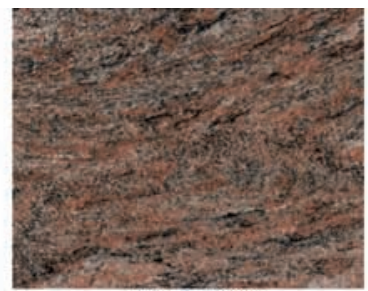

Indian Creek

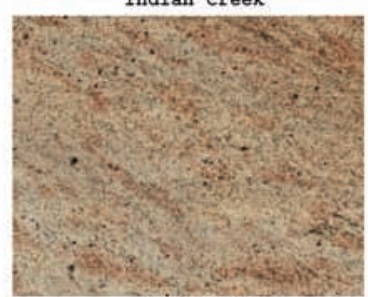

Monterrey

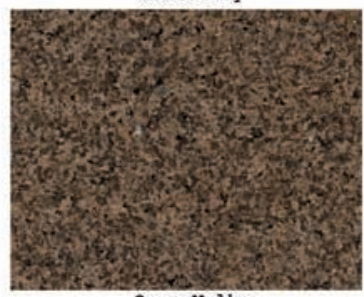

Ouro Velho
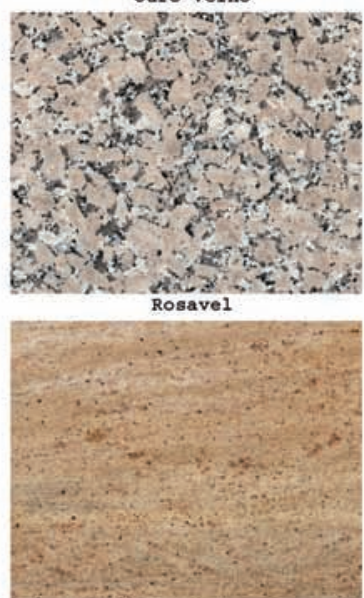

Santa Barbara

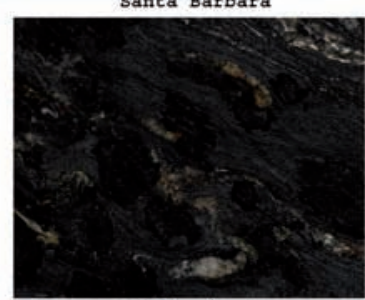

Titanium

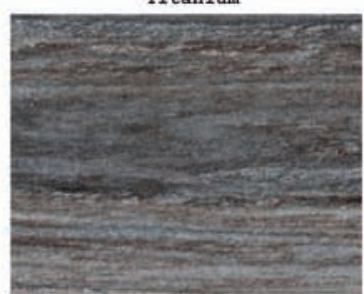

Zeus

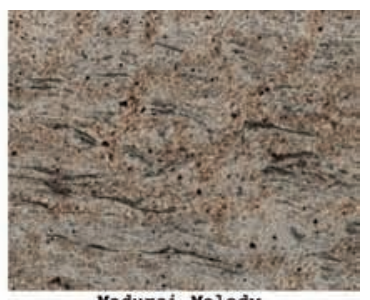

Madurai Melody

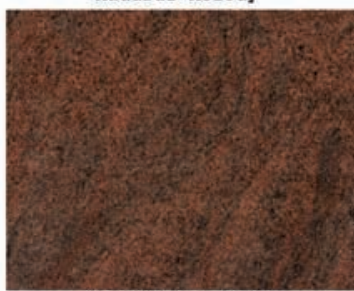

Multicolor Rojo

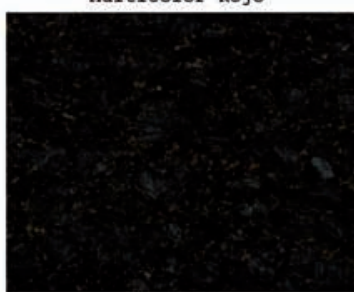

Peacock

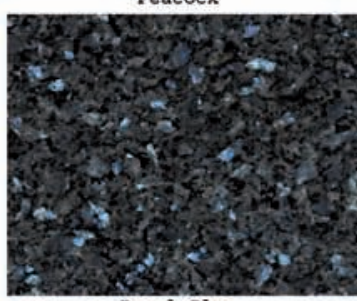

Royal Blue

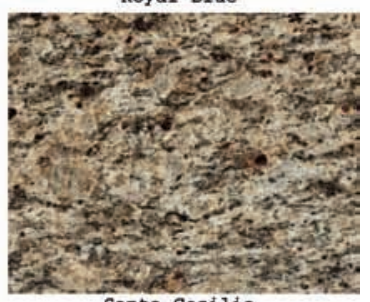

Santa Cecilia

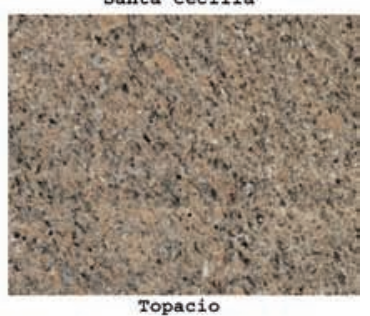

Topacio

Figure 12. Images of different granite varieties used in the tests.

Figura 12. Imágenes de diferentes variedades de granito empleadas en las pruebas. 


\begin{tabular}{|c|c|c|c|c|c|c|c|}
\hline \multicolumn{6}{|c|}{ Matriz de confusión } & \multicolumn{2}{|c|}{$-\square x$} \\
\hline & \multicolumn{7}{|c|}{ Variedad } \\
\hline & \multicolumn{4}{|c|}{ Porvariables } & \multicolumn{3}{|c|}{ Por comp. princ. } \\
\hline & № & Err. & & Bondad & Err. & & Bondad \\
\hline A. Boreal & 4 & 0 & 0,0 & 68,67 & 0 & 0,0 & 323,13 \\
\hline Artic Blue & 4 & 0 & 0,0 & 5,88 & 0 & 0,0 & 6,90 \\
\hline Azul Arán & 4 & 0 & 0.0 & 87,58 & 0 & 0,0 & 252,90 \\
\hline Azul Noche & 4 & 0 & 0,0 & 52,51 & 0 & 0,0 & 24,71 \\
\hline Azul Platino & 4 & 0 & 0,0 & 36,07 & 0 & 0,0 & 222,03 \\
\hline Barracuda & 4 & 0 & 0.0 & 31,82 & 0 & 0,0 & 57,22 \\
\hline Blanco Alfa & 4 & 0 & 0,0 & 0,99 & 0 & 0,0 & 7,59 \\
\hline Blanco Cristal & 4 & 0 & 0,0 & 169.99 & 0 & 0,0 & 403,20 \\
\hline Blanco Romano & 4 & 0 & 0,0 & 9,69 & 0 & 0,0 & 52,80 \\
\hline Blue Eyes Pearl & 4 & 0 & 0,0 & 5,83 & 0 & 0,0 & 7,53 \\
\hline Blue Pearl GT & 4 & 1 & 25,0 & 3,53 & 0 & 0,0 & 3,09 \\
\hline Brazilian Viara & 4 & 0 & 0,0 & 92,71 & 0 & 0,0 & 75,75 \\
\hline Cacao Blue & 4 & 0 & 0,0 & 53,15 & 0 & 0,0 & 72,78 \\
\hline Camel Suede & 4 & 0 & 0,0 & 21,00 & 0 & 0,0 & 163.15 \\
\hline Canary & 4 & 0 & 0.0 & 41,41 & 0 & 0,0 & 79,04 \\
\hline Capao Bonito & 4 & 0 & 0,0 & 94,16 & 0 & 0,0 & 117,03 \\
\hline Cindy & 4 & 0 & 0.0 & 38,59 & 0 & 0,0 & 156,06 \\
\hline Cinnamon & 4 & 0 & 0,0 & 20,77 & 0 & 0,0 & 141,51 \\
\hline Cohiba & 4 & 1 & 25,0 & 0.42 & 1 & 25,0 & 0.76 \\
\hline Coral Reef & 8 & 0 & 0,0 & 1.59 & 0 & 0,0 & 0,76 \\
\hline Dragon Red & 4 & 0 & 0,0 & 41,16 & 0 & 0,0 & 142,01 \\
\hline Ebb Tide & 4 & 0 & 0,0 & 178,48 & 0 & 0,0 & 651,67 \\
\hline Emerald Pearl & 4 & 0 & 0,0 & 0,42 & 1 & 25,0 & 0.26 \\
\hline Galacy & 4 & 0 & 0,0 & 0.96 & 0 & 0,0 & 1,37 \\
\hline Ghibli & 4 & 0 & 0.0 & 27.79 & 0 & 0,0 & 129,00 \\
\hline Golden Artico & 4 & 0 & 0,0 & 25,11 & 0 & 0,0 & 220,23 \\
\hline Golden Colombo & 4 & 0 & 0,0 & 52,26 & 0 & 0,0 & 141,84 \\
\hline Gran Beige & 4 & 0 & 0,0 & 42,42 & 0 & 0,0 & 315,46 \\
\hline Gran Gris & 4 & 0 & 0,0 & 21,96 & 0 & 0,0 & 564,85 \\
\hline Havana Brown & 4 & 0 & 0,0 & 67,84 & 0 & 0,0 & 145,99 \\
\hline Indian Creek & 4 & 0 & 0,0 & 156,07 & 0 & 0,0 & 292,92 \\
\hline Madurai Melody & 4 & 0 & 0,0 & 30,69 & 0 & 0,0 & 116,91 \\
\hline Marisma & 4 & 0 & 0,0 & 60,89 & 0 & 0,0 & 103,89 \\
\hline Mellow Brown & 4 & 1 & 25,0 & 1,90 & 1 & 25,0 & 2.79 \\
\hline Monterrey & 4 & 0 & 0,0 & 14,42 & 0 & 0,0 & 44,37 \\
\hline Multicolor Red & 4 & 0 & 0,0 & 45,04 & 0 & 0,0 & 61,32 \\
\hline Multicolor Rojo & 4 & 0 & 0,0 & 33,45 & 0 & 0,0 & 35,72 \\
\hline Negro Absoluto & 4 & 0 & 0,0 & 0,67 & 0 & 0,0 & 0,89 \\
\hline Ornamental & 4 & 0 & 0.0 & 106,61 & 0 & 0,0 & 488.33 \\
\hline Ouro Velho & 4 & 0 & 0,0 & 57,52 & 0 & 0,0 & 306,36 \\
\hline Peacock & 4 & 0 & 0,0 & 1,38 & 0 & 0,0 & 2,73 \\
\hline Polar & 4 & 0 & 0,0 & 21,06 & 0 & 0,0 & 1019,20 \\
\hline Quati Blue & 4 & 0 & 0.0 & 28,58 & 0 & 0,0 & 63,80 \\
\hline Rosavel & 4 & 0 & 0,0 & 71,41 & 0 & 0,0 & 671,06 \\
\hline Royal Blue & 4 & 0 & 0,0 & 42,90 & 0 & 0,0 & 37,14 \\
\hline Sahara Nights & 4 & 0 & 0,0 & 0.57 & 0 & 0,0 & 0,66 \\
\hline San Francisco & 4 & 0 & 0,0 & 41,95 & 0 & 0,0 & 109,67 \\
\hline Santa Bárbara & 8 & 0 & 0.0 & 1.71 & 2 & 25,0 & 1,13 \\
\hline Santa Cecilia & 4 & 0 & 0,0 & 28,85 & 0 & 0,0 & 152,05 \\
\hline Shivakashi & 4 & 0 & 0,0 & 82,58 & 0 & 0,0 & 562,17 \\
\hline Terracota & 4 & 0 & 0,0 & 64,48 & 0 & 0,0 & 182,16 \\
\hline Titanium & 4 & 0 & 0,0 & 15,66 & 0 & 0,0 & 14,78 \\
\hline Topacio & 4 & 0 & 0,0 & 21,47 & 0 & 0,0 & 73,59 \\
\hline Tropic Brown & 4 & 0 & 0,0 & 106,14 & 0 & 0,0 & 342,57 \\
\hline Vicenza & 4 & 0 & 0,0 & 75,53 & 0 & 0.0 & 200,10 \\
\hline Zeus & 4 & 0 & 0,0 & 34,74 & 0 & 0,0 & 141,70 \\
\hline Totales & 232 & 3 & 1,3 & 19,00 & 5 & 2,2 & 49,67 \\
\hline
\end{tabular}

Figure 13. Results of a sorting test on many granite varieties. Figura 13. Resultados de un ensayo de identificación de numerosas variedades de granito. a granite processing plant, whether the material is dry or wet.

The use of this system in a granite processing plant would significantly improve the management of product batches in the warehouse and ensure the concordance of a shipment to previous shipments or to a sample provided by the customer.

Unfortunately, the operation of the system could not be finally validated in an actual processing plant, as the situation of the natural stone industry at the termination of the project in 2007 was critical and, despite all our efforts, companies were not willing to evaluate a demonstration system. In fact, many companies in the sector were forced to close down, among them Levantina Pavimentos de Granito S.A., who owned the plant that provided the granite samples used for the development of this project.

However, the situation has improved considerably nowadays, and we expect to be able to test the system in a processing plant in the not-so-distant future, as its advantages have been clearly demonstrated.

\section{Acknowledgements}

This research is derived from the participation of its authors in a research project funded by the Ministry of Industry, Tourism and Trade with reference FIT380000-2005-157 and FIT-380000-2006-22, titled “Sistema para la clasificación automática de piezas elaboradas y semielaboradas de granito según su tono mediante visión artificial".

We are also very grateful to the management and technicians of the processing plant of Levantina Pavimentos de Granito S.A. at Cadalso de los Vidrios (Madrid), whose support was crucial to the success of the project.

\section{References}

Araújo, M., Martínez, J., Ordóñez, C. and Vilán, J.A. 2010. Identification of Granite Varieties from Colour Spectrum Data. Sensors, Volume 10, Issue 9, 8572-8584. http://www.mdpi.com/1424-8220/10/9/8572

Bianconi, F., González, E., Fernández, A. and Saetta, S.A. 2012. Automatic classification of granite tiles through colour and texture features. Expert Systems with Applications, Volume 39, Issue 12, 11212-11218.

Catalina, J.C. and Fernández, G. 2007. Sistema de clasificación automática de piezas de granito según su tono mediante visión artificial. $12^{\text {th }}$ International Congress on Energy and Mineral Resources, Oviedo, Spain, 7-11 October.

Catalina, J.C., Fernández, G. and Alarcón, D. 2010. 
Automatic tone grading system for granite tiles. Global Stone Congress 2010, Alicante, Spain, 2-5 March.

Clemente-Pérez, P., Garcerán-Hernández, V., Puyosa-Piña, H.D. and Tomás-Balibrea, L.M. 1995. Automatic system to quality control: Using artificial vision and neural nets for classification of marble slabs in production line, in Proceedings of International Symposium on Artificial Neural Networks, Taiwan, R.O.C., E3.26-E3.31.

International Commission on Illumination. 2007. CIE S 0144/E:2007. Colorimetry-part 4: CIE $1976 L^{*} a * b *$ Colour Space; CIE Central Bureau: Vienna, Austria.

Martinez-Alajarín, J., Luis-Delgado, J. D. and TomásBalibrea, L.M. 2005, Automatic system for quality-based classification of marble textures, IEEE Transactions on Systems, Man, and Cybernetics, Part C 35 (4), 488-497.

Martínez-Alajarín, J. and Tomás-Balibrea, L.M. 1999. Automatic classification system of marble slabs in production line according to texture and color using artifi- cial neural networks, in Proc. $8^{\text {th }}$ Int. Conf. Computer Analysis of Images and Patterns, Ljubljana, Slovenia, Sep. 1999, pp. 167-174.

Muge, F., Pina, P., Ramos, V., Sottomayor, L., Bruno, R., Bedeschi, I., Mengucci, M., Lamberti, C., Brancaleoni, F., Proverbio, M., Corbelli, O., Chica-Olmo, M., Serrano, E., Quereda, J.M. and Sanchez, G. 1997. Characterization of Ornamental Stones Standards by Image Analysis of Slab Surface (COSS), Eurominerals 97, II International Congress of Natural and Industrial Stones, Lisboa, 4-6 June.

Ramos, V., Pina, P. and Muge, F. 1999. From Feature Extraction to Classification: A multidisciplinary Approach applied to Portuguese Granites, in Ersboll B.K., Johansen P. (eds.), Proceedings of SCIA'99-The $11^{\text {th }}$ Scandinavian Congress on Image Analysis, volume 2, 817-824, Kangerlussuaq, Greenland. The paper was republished in 2004 in CoRR abs/cs/0412066

Recibido: diciembre 2015

Revisado: febrero 2016

Aceptado: marzo 2016

Publicado: junio 2017 